\title{
REGIONAL DIVERSITY OF ORGANIC FOOD SALES IN THE EUROPEAN UNION
}

\author{
Adam Pawlewicz ${ }^{1}$, Ph.D \\ ${ }^{1}$ Department of Agrotechnology, Agricultural Production Management and Agribusiness, University of Warmia and \\ Mazury in Olsztyn, Poland
}

\begin{abstract}
The article discusses regional differences on the organic food market in the European Union based on retail sales data. The analysis was based on Eurostat, FiBL, IFOAM, USDA and literature data for 2016. Selected descriptive statistics were used. The analysis demonstrated considerable regional differences in both total and per capita retail sales of organic food on the EU market, which can be attributed to the unique characteristics of the compared countries. The absolute values of organic retail sales are influenced mainly by population and GDP. Per capita sales are strongly determined by GDP and final consumption expenditure of household. Therefore, organic retail sales were higher in countries with a higher GDP and higher household consumption per capita. Organic food sales and consumption were highest in Germany, France, Italy, the UK and Switzerland. The analysed variables were lowest in Cyprus, Slovakia, Lithuania, Latvia, Bulgaria, Hungary and Estonia.
\end{abstract}

Key words: organic market, organic farming, UE, organic food consumption, retail sales, expenses.

JEL code: D40, E21, I15, O1, Q13,

\section{Introduction}

Public concerns over environmental protection and food safety have been growing in Europe since the mid 1980s (Greenan K., Humphreys P., McIvor R., 1997). Consumers have a growing awareness about the harmful environmental impacts of conventional agriculture and the health implications of highly processed foods. Environmentally- and health-conscious consumers are increasingly likely to buy organic foods (Krystallis A., Chryssohoidis G., 2005). Organic farming is an agricultural management and production system that combines the most environmentally-sound practices with high levels of biological diversity, protection of natural resources, high animal welfare standards and production methods that meet the consumers' demand for foods produced with the involvement of natural substances and processes (Council Regulation (EC) No 834/2007). Most research studies indicate that consumers are more inclined to buy organic food due to the associated health benefits rather than for environmental reasons. According to most consumers, their purchasing decisions are more likely to be influenced by the unique attributes of organic food products that deliver direct benefits rather than the specific features of the organic production process that deliver indirect benefits for consumers (Wier M., Calverley C., 2002). For this reason, consumers increasingly often turn to foods produced in organic farms. This trend can also be attributed to an increase in disposable incomes in highly developed countries which have the largest organics markets. In contrast, high price premiums continue to suppress the demand for and the consumption of organic foods in less developed countries (Shafie F.A., Rennie D., 2012). Despite the above, the organic food sector has been the most dynamically growing segment of the European agrifood market in the past two decades. The above can be attributed to the high quality of organic foods, environmental concerns, healthy lifestyle and health problems, which are the top reasons given for buying organics (Basha M.B., Mason C., Shamsudin M.F., Hussain H.I., Salem M.A., 2015). At the same time, organic farming area and the number of organic food producers continue to increase despite strict regulations. Organic food production is highly subsidized (Brodziska K., 2015), which does not always contribute to an increase in the supply of organics in less developed countries, including Poland (Pawlewicz A., 2014). Despite the above, the sales of organic raw materials and processed products continue to increase each year around the world. This trend is observed in both highly developed countries as well as in less affluent states. In view of the above, two research hypotheses were tested in this study: $\mathrm{H} 1$ - organic retail sales differ across the EU; and H2 -

\footnotetext{
${ }^{1}$ Corresponding author. Tel.: +4889 52333 13; e-mail address: adampawl@uwm.edu.pl
} 
organic retail sales are higher in countries with a higher GDP and higher household consumption expenditures. Therefore, the aim of this study was to evaluate the differences on the organic food market in the European Union based on organic retail sales.

In the first stage of the analysis, the research goal was pursued by selecting parameters describing organic retail sales in the EU countries based on statistical data. The analysed parameters were organic retail sales (million $€$ ), per capita consumption ( $€$ per capita), organic crop area (fully converted and under conversion to organic farming, ha); area under organic farming ( $\%$ of utilised agricultural area (UAA)); population, exports of organic foods (million $€$, for countries where these data were available), main GDP aggregates per capita ( $€$ per capita), final consumption expenditure of households (total - million $€$ and $€$ per capita). Sales data were not available for all EU countries, and they were estimated by predicting the dependent variable based on literature data, media reports or the situation in countries with a similar level of development (as indicated in Table 2).

The analysis was based on Eurostat, Research Institute of Organic Agriculture (FiBL), Frick, and IFOAM - Organics International and U.S. Department of Agriculture (USDA) data. Some data were obtained from websites dedicated to domestic organic food markets. The data applicable to Malta were excluded from the analyses due to their incidental nature, and the information pertaining to Norway and Switzerland was included due to high organic sales and data completeness. The data for 2016 were subjected to a vertical analysis, whereas the data for 2004-2016 were processed by horizontal analysis. For comparative purposes, the analysed data were standardized based on the Harmonized Index of Consumer Prices (HICP) published by Eurostat. Selected descriptive statistics were used to determine regional variations, including the arithmetic mean, median, minimum, maximum and the coefficient of variation (Vc). Pearson's correlation coefficient was calculated to determine the relationships between the analysed parameters.

\section{Research results and discussion}

Organic farming area, including fully converted farms as well as farms under conversion, continues to increase around the world each year. Organic farming area increased from 35 million hectares in 2008 to nearly 58 million hectares in 2016, but it still accounts for only $1.2 \%$ of total agricultural area in the world. Oceania (Australia) has a nearly $50 \%$ share of global organics production, whereas Europe, mostly EU countries, has a nearly $25 \%$ share. Oceania (Australia) also has the highest organic share of the total agricultural land $-6.5 \%$, followed by Europe $-2.7 \%$. In contrast, Asia and Africa have the highest number of organic producers in the world, which, combined with a small share of organic areas in their total agricultural land, points to considerable dispersion of small organic farms. Organic retail sales and per capita consumption were highest in North America and Europe (Table 1).

Table 1

Organic farming and the global organic food market in 2016

\begin{tabular}{|l|c|c|c|c|c|c|}
\hline \multicolumn{1}{|c|}{ Region } & $\begin{array}{c}\text { Organic } \\
\text { agr. land }\end{array}$ & Share & $\begin{array}{c}\text { Numbers } \\
\text { of } \\
\text { producers }\end{array}$ & $\begin{array}{c}\text { Share of } \\
\text { total agri. } \\
\text { land }\end{array}$ & Retail sales & $\begin{array}{c}\text { Per capita } \\
\text { consumption }\end{array}$ \\
\hline Africa & ha & $\%$ & no & $\%$ & Million $€$ & $€$ \\
\hline Asia & 1801699 & 3.12 & 741367 & 0.2 & 16 & - \\
\hline Europe & 4897837 & 8.47 & 1108040 & 0.3 & 7343 & 1.7 \\
\hline Latin America & 13509146 & 23.36 & 373240 & 2.7 & 33526 & $* 40.8$ \\
\hline North America & 3135155 & 12.34 & 458532 & 0.9 & 810 & 1.3 \\
\hline Oceania & 27346986 & 5.41 & 18422 & 0.8 & 41939 & 117.0 \\
\hline World & 57821155 & 100 & 2726967 & 1.2 & 84698 & 26.5 \\
\hline$U E$ in 2016 - $60.1 €$ & & & & & 11.3 \\
\hline
\end{tabular}


Source: author's calculations based on The World of Organic Agriculture. Statistics and Emerging Trends 2018. Willer, Helga and Julia Lernoud (Eds.). Research Institute of Organic Agriculture (FiBL), Frick, and IFOAM - Organics International, Bonn, 2018, p. 348.

Organic retail sales continue to increase in the European Union (and in all of Europe) each year. In 2004, the value of the EU organic market exceeded 8 billion $€$. The market grew by $14 \%$ in 2005, and this dynamic increase was maintained until 2007 (16.2\% increase to more than 12.3 billion $€$ relative to 2006 ).

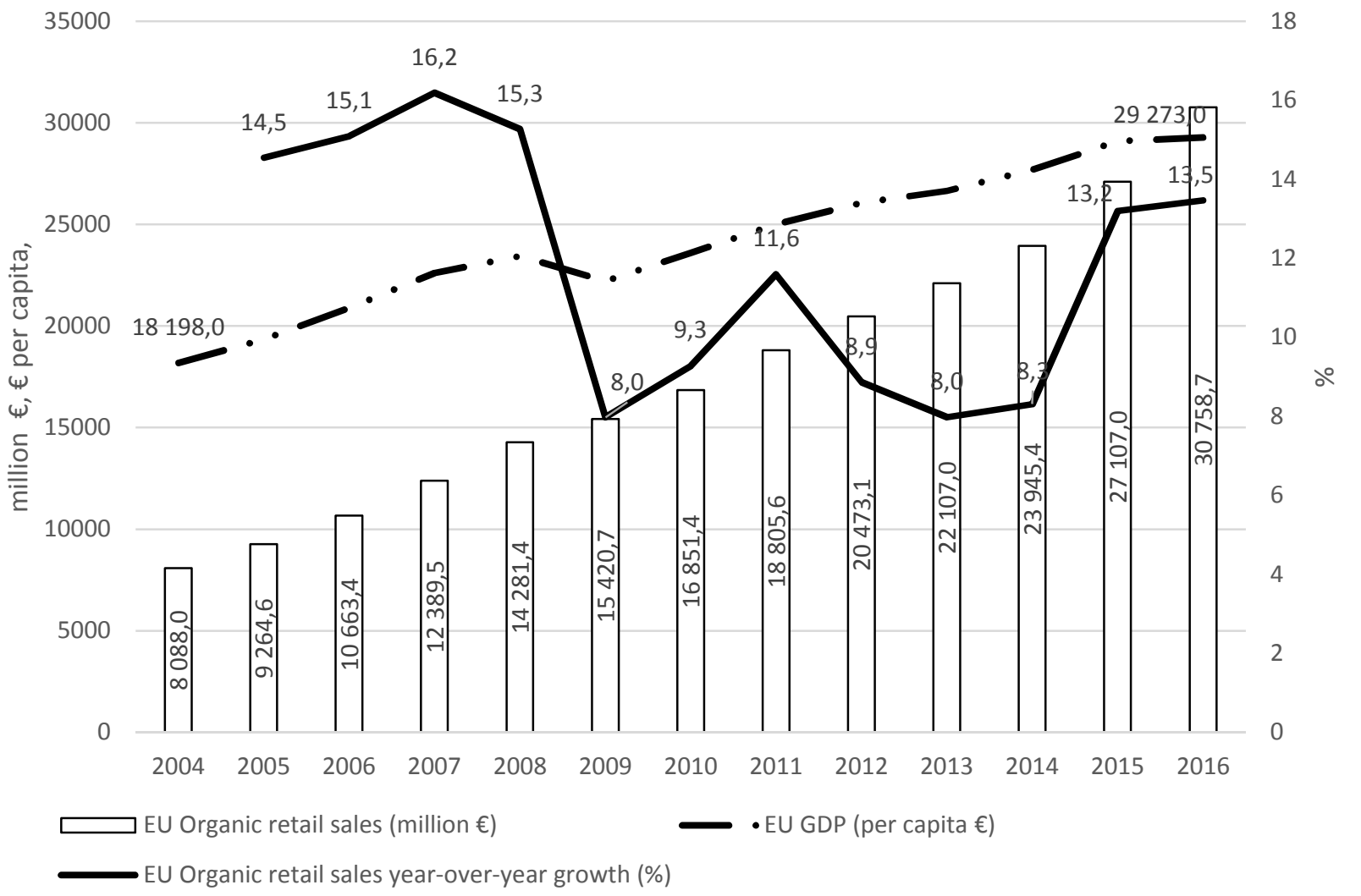

HICP-administered prices $(2015=100)$

Source: author's calculations based on The World of Organic Agriculture. Statistics and Emerging Trends 2018. Willer, Helga and Julia Lernoud (Eds.). Research Institute of Organic Agriculture (FiBL), Frick, and IFOAM - Organics International, Bonn, 2018, p. 348; HICP (2015 = 100) - annual data (average index and rate of change) [prc_hicp_aind] Eurostat. https://ec.europa.eu/eurostat/data/database. Access: 10.12.18; Main GDP aggregates per capita [nama_10_pc] Eurostat. https://ec.europa.eu/eurostat/data/database. Access: 07.12.18.

Fig. 1. Organic retail sales and their growth rates in the EU in 2004-2016 at constant prices in 2015

Organic retail sales slowed down after 2008, and year-over-year growth reached $15.3 \%$. In 2009, the market grew at $8 \%$ with sales reaching nearly 15.5 billion $€$. The above can be linked to the global financial crisis of 2008-2009. Negative changes were also observed on agricultural markets (Borawski P., BeldyckaBorawska A., Dunn J.W., 2018), which weakened the consumers' purchasing power and influenced decision-making on the organic market (Orboi M.D., 2013). The above observations are highly consistent with the drop in GDP per capita (in $€$ ) in the EU in the corresponding time period. A new period of dynamic growth on the organic market began in 2009, and sales reached 18.8 billion $€$ in 2011. By 2013, market growth decreased to $8 \%$ relative to 2012. Despite this slowdown, the organic food market continued to increase to 22.1 billion $€$. Year-over-year growth increased between 2013 and 2015 when the market was valued at 27.1 billion $€$. In 2016, the growth rate decreased and retail sales topped 30.7 billion $€$ (fig. 1).

Differences in value of the organic food market were evaluated based mainly on an analysis of retail sales. The coefficient of variation for organic retail sales revealed extreme heterogeneity $(\mathrm{Vc}=184.4 \%)$ among the analysed countries, with an average value of 1157.3 million $€$ and a median of 150 million $€$. Organic retail sales are highest in Western Europe, and Germany is the largest market (9 478 million $€$ ). In 2016, organic retail sales were also high in France (6 736 million $€$ ), Italy (2 644 million $€$ ), the United 
Kingdom (2 460 million $€$ ) and Switzerland (2 298 million $€$ ). Relatively high values were also noted in Sweden (1 944 million $€$ ), Spain (1 686 million $€$ ), Austria (1 542 million $€$ ), Denmark (1 298 million $€$ ) and Netherlands ( 1171 million $€$ ). Organic retail sales were lowest in Cyprus ( 2 million $€$ ), Slovakia (4 million $€$ ), Lithuania (10 million $€$ ), Latvia (10 million $€$ ), Bulgaria (27 million $€$ ), Hungary (35 million $€$ ), Estonia (36.6 million $€$ ), Portugal (38.8 million $€$ ), Romania (39.5 million $€$ ). Detailed data are presented in Table 2.

The observed differences can be attributed mainly to differences in the economic development of the analysed countries. Organic retail sales peaked in highly developed European countries characterized by high incomes and high levels of environmental, economic and health awareness where high price premiums do not drive down sales. It should also be noted that organic production in the "new" EU Member States is mostly export-oriented (Orboi M.D., 2013). This observation is validated by statistical data which indicate that final consumption expenditure of households (million $€)(r=0.858 ; p<0.001)$ and population $(r=0.813$; $\mathrm{p}<0.001$ ) are bound by a strong positive correlation with organic retail sales. It should also be noted a fairly weak relationship indicating that, with the growing general retail sales, sales per capita are growing $(r=0.372, p<0.05)$ (Table 3$)$.

The per capita consumption of organic food is an equally important indicator of the size of organic markets, and it supports a comparison of European regions. Consumption levels are a reflection of the purchasing power and the environmental awareness of consumers who are willing to buy more expensive organic products. Therefore, per capita expenditure can be regarded as a measure of the standard of living. Per capita retail organic sales in the EU were highly varied in the analysed year ( Vc $=123.5 \%$ ), with an average of more than $62 €$ (in UE 60.1 $€$ ) and a median of 32,7€. Spending on organic food was highest in the Scandinavian and Alpine countries, including Switzerland - $276 €$, Denmark - $227.4 €$, Sweden $197.3 €$, Luxembourg - 187.4 $€$ and Austria - 177.2 $€$. In Germany $(115.3 €)$ and France $(100.9 €)$, the average retail sales per capita were less than half the values reported in Switzerland. The lowest retail sales per capita were noted in Slovakia - $0.7 €$, Romania $-2 €$, Lithuania $-3.5 €$, Hungary $-3.6 €$, Bulgaria - $3.8 €$ and Portugal $-3.8 €$ (Table 2). These findings emphasize the dominant role of affluent countries where high price premiums do not decrease the demand for organic food. 
Variables characterizing the organic food market in the EU in 2016

\begin{tabular}{|c|c|c|c|c|c|c|c|c|c|}
\hline & $\mathbf{A}$ & B & C & D & $\mathbf{E}$ & $\mathbf{F}$ & $\mathbf{G}$ & $\mathbf{H}$ & $\mathbf{I}$ \\
\hline Specification & ha & $\begin{array}{c}\% \\
\text { of } \\
\text { UAA }\end{array}$ & Million $\mathbf{C}$ & $\begin{array}{l}\mathcal{C} \text { per } \\
\text { capita }\end{array}$ & persons & $\begin{array}{l}\text { Million } \\
\mathbf{C}\end{array}$ & $\begin{array}{l}C \text { per } \\
\text { capita }\end{array}$ & Million $\mathbf{C}$ & $\begin{array}{l}\boldsymbol{C} \text { per } \\
\text { capita }\end{array}$ \\
\hline EU & 11931885 & 6.7 & 30758.7 & 60.1 & 510277177 & & 29200 & 8098087.1 & 15870.0 \\
\hline Austria & 571423 & 21.3 & 1542 & 177.2 & 8700471 & & 40800 & 178675.5 & 20536.3 \\
\hline Belgium & 78452 & 5.8 & 586 & 51.8 & 11311117 & & 37600 & 212141.5 & 18755.1 \\
\hline Bulgaria & 160620 & 3.2 & $* * 27$ & 3.8 & 7153784 & & 6800 & 28998.2 & 4053.6 \\
\hline Croatia & 93593 & 6.1 & $* 137.1$ & 32.7 & 4190669 & & 11200 & 26072.7 & 6221.6 \\
\hline Cyprus & 5550 & 4.9 & $* * 2$ & 5.0 & 848319 & & 21700 & 12507.4 & 14743.8 \\
\hline Czechia & 488591 & 14.0 & $* 80.2$ & 7.6 & 10553843 & 59 & 16700 & 81862.7 & 7756.7 \\
\hline Denmark & 204950 & 7.8 & 1298 & 227.4 & 5707251 & 329 & 49200 & 128014 & 22430.1 \\
\hline Estonia & 180852 & 18.0 & $* * * 36.6$ & 27.8 & 1315944 & & 16500 & 10777.3 & 8189.8 \\
\hline Finland & 238240 & 10.5 & 273 & 49.8 & 5487308 & & 39300 & 113372 & 20660.8 \\
\hline France & 1537351 & 5.3 & 6736 & 100.9 & 66730453 & 629 & 33300 & 1164859 & 17456.2 \\
\hline Germany & 1135941 & 6.8 & 9478 & 115.3 & 82175684 & & 38400 & 1622135 & 19739.8 \\
\hline Greece & 342584 & 6.5 & $* * 95$ & 8.8 & 10783748 & & 16400 & 117180.6 & 10866.4 \\
\hline Hungary & 186322 & 3.5 & $* * 35$ & 3.6 & 9830485 & & 11600 & 54691.4 & 5563.5 \\
\hline Ireland & 76701 & 1.7 & 150 & 31.7 & 4726286 & & 57500 & 89465.4 & 18929.3 \\
\hline Italy & 1796333 & 14.0 & 2644 & 43.6 & 60665551 & 1915 & 27900 & 1012573.2 & 16691.1 \\
\hline Latvia & 259146 & 13.4 & $* * 10$ & 5.1 & 1968957 & & 12800 & 14751.1 & 7491.8 \\
\hline Lithuania & 221665 & 7.5 & 10 & 3.5 & 2888558 & & 13500 & 24782.6 & 8579.6 \\
\hline Luxembourg & 4528 & 3.5 & 108 & 187.4 & 576249 & & 91300 & 15400.1 & 26724.7 \\
\hline Netherlands & 52204 & 2.9 & 1171 & 69.0 & 16979120 & 1200 & 41600 & 310430 & 18283.0 \\
\hline Norway & 47621 & 4.9 & 394 & 75.6 & 5210721 & & 64100 & 143778.1 & 27592.8 \\
\hline Poland & 536579 & 3.7 & $* * 219.7$ & 5.8 & 37967209 & & 11100 & 246103.8 & 6482.0 \\
\hline Portugal & 245052 & 6.8 & $* * * 38.85$ & 3.8 & 10341330 & & 18100 & 118037 & 11414.1 \\
\hline Romania & 226309 & 1.7 & $* * 39.55$ & 2.0 & 19760314 & & 8600 & 105083.9 & 5317.9 \\
\hline Slovakia & 187024 & 9.8 & 4 & 0.7 & 5426252 & & 15000 & 43579.1 & 8031.2 \\
\hline Slovenia & 43579 & 9.1 & $* 58.68$ & 28.4 & 2064188 & & 19500 & 21187 & 10264.1 \\
\hline Spain & 2018802 & 8.5 & 1686 & 36.3 & 46440099 & 891 & 24100 & 631793 & 13604.5 \\
\hline Sweden & 552695 & 18.3 & 1944 & 197.3 & 9851017 & 84 & 46700 & 200784 & 20382.1 \\
\hline Switzerland & 141249 & 13.5 & 2298 & 276.0 & 8327126 & & 72400 & 313597.3 & 37659.7 \\
\hline UK & 490205 & 2.8 & 2460 & 37.6 & 65382556 & & 36600 & 1507354.7 & 23054.4 \\
\hline $\begin{array}{l}\text { arithmetic } \\
\text { mean }\end{array}$ & 418074.5 & 8.1 & 1157.3 & 62.61 & 18047055.5 & 729.6 & 31044.8 & 294827.2 & 15085.4 \\
\hline median & 221665 & 6.8 & 150 & 32.72 & 8700471 & 629.0 & 24100.0 & 117180.6 & 14743.8 \\
\hline $\begin{array}{l}\text { minimum } \\
\text { value }\end{array}$ & 4528 & 1.7 & 2 & 0.7 & 576249 & 59.0 & 6800.0 & 10777.3 & 4053.6 \\
\hline $\begin{array}{l}\text { maximum } \\
\text { value }\end{array}$ & 2018802 & 21.3 & 9478 & 276.0 & 82175684 & 1915.0 & 91300.0 & 1622135.0 & 37659.7 \\
\hline $\begin{array}{l}\text { standard } \\
\text { deviation }\end{array}$ & 531369.3 & 5.3 & 2133.4 & 77.3 & 23163736.9 & 669.5 & 21004.6 & 449129.4 & 8116.0 \\
\hline $\begin{array}{l}\text { coefficient } \\
\text { of variation }\end{array}$ & 127.1 & 64.9 & 184.4 & 123.5 & 128.4 & 91.8 & 67.7 & 152.3 & 53.8 \\
\hline
\end{tabular}

Estimates based on: * predictions of the dependent variable; ** literature data or media reports; *** analogy (\%) with countries with similar levels of development.

A - Total fully converted and under conversion to organic farming; B - Area under organic farming ( \% of utilised agricultural area (UAA)); C - Retail sales, D - Per capita consumption; E - Population; F - Exports; G - Main GDP aggregates per capita; H, I - Final consumption expenditure of households

Source: author's calculations based on The World of Organic Agriculture. Statistics and Emerging Trends 2018 . Willer,

Helga and Julia Lernoud (Eds.). Research Institute of Organic Agriculture (FiBL), Frick, and IFOAM - Organics

International, Bonn, 2018, p. 348 (ABCDF); Population on 1 January by age and sex [demo_pjan] Eurostat.

https://ec.europa.eu/eurostat/data/database. Access: 11.12.18(E); Main GDP aggregates per capita [nama_10_pc]

Eurostat. https://ec.europa.eu/eurostat/data/database. Access: 07.12.18 (G); GDP and main components (output, 
expenditure and income) [nama_10_gdp] Eurostat. https://ec.europa.eu/eurostat/data/database. Access: 11.12 .18 (HI).

The discussed phenomenon is validated by the results of the correlation analysis which revealed a strong correlation between the size of the organic food market and the levels of economic development in the analysed countries. Organic retail sales per capita increased with a rise in GDP per capita ( $€$ per capita; $r=0.773 ; p<0.001)$. Per capita consumption of organic products also increased with a rise in Final consumption expenditure of households ( $€$ per capita) $(r=0.797 ; p<0.001)$ (Table 3$)$.

\section{Descriptive statistics and matrix of coefficients of correlation between variables} $(\mathbf{N}=29)$

\begin{tabular}{|r|r|r|r|r|r|r|r|r|r|r|r|}
\hline & \multicolumn{1}{|c|}{ Mean } & \multicolumn{1}{c|}{ SD } & \multicolumn{1}{c|}{ A } & \multicolumn{1}{c|}{ B } & \multicolumn{1}{c|}{ C } & D & E & F & G & H & I \\
\hline A & 418074.5 & 531369.3 & 1 & & & & & & & & \\
\hline B & 8.1 & 5.3 & .200 & 1 & & & & & & \\
\hline C & 1157.3 & 2133.4 & $* .613$ & .041 & 1 & & & & & & \\
\hline D & 62.6 & 77.3 & .038 & .341 & $* * * .372$ & 1 & & & & & \\
\hline E & 18047055.5 & 23163736.9 & $* .785$ & -.143 & $* .813$ & .016 & 1 & & & & \\
\hline F & 729.6 & 669.5 & .479 & -.252 & .169 & -.426 & .619 & 1 & & & \\
\hline G & 31044.8 & 21004.6 & -.095 & .011 & .216 & $* .773$ & -.029 & -.161 & 1 & & \\
\hline H & 294827.2 & 449129.4 & $* .681$ & -.091 & $* .858$ & .145 & $* .956$ & $* * .943$ & .126 & 1 & \\
\hline I & 15085.4 & 8116.0 & .024 & .112 & .350 & $* .797$ & .124 & .077 & $* .916$ & .307 & 1 \\
\hline
\end{tabular}

correlation coefficient significant at $* 0.001, * * 0.01$ and $* * * 0.05$

where: A - Total fully converted and under conversion to organic farming (ha); B - Area under organic farming ( \% of utilised agricultural area (UAA)); C - Retail sales (Million C); D - Retail sales (C per capita); $E$ - Population; $F$ - Export (Million $C, N=7$ ); $G$ - Main GDP aggregates per capita (C per capita); $H$ - Final consumption expenditure of households (Million C); I - Final consumption expenditure of households (C per capita)

Source: author's calculations based on data from Table 2

\section{Conclusions, proposals, recommendations}

The organic food market continues to grow on all continents, but the highest growth rates are observed in Europe. The above is driven by higher demand for organic food, which can be attributed to growing levels of environmental and health awareness as well as an increase in the purchasing power of European consumers. At the same time, organic farming subsidies increase production levels and, consequently, augment the supply of organic products. Price premiums stifle demand and pose the greatest obstacle to the development of the organic food market. The differences in the prices of organically and conventionally produced foods are likely to diminish with an increase in the supply of organic food products, which will drive the demand for such products.

The results of this analysis point to considerable differences in the retail sales and per capita consumption of organic food in the EU. The observed variations can be attributed mainly to heterogeneity in economic development expressed by GDP and consumer expenditure in the evaluated countries. The analysis also revealed an interesting relationship. In absolute terms, organic retail sales are determined mainly by population and GDP per capita, which indicates that organic sales are highest in the countries with a high number of relatively wealthy inhabitants. In turn, organic consumption per capita is strongly affected by GDP and consumption expenditure. Therefore, countries with a higher GDP per capita and higher final consumption expenditure of household are characterized by higher retail organic sales. The analysis revealed that the sales and consumption of organic food are highest in Germany, France, Italy, the UK and Switzerland, whereas per capita consumption is highest in Switzerland, Denmark, Sweden, Luxembourg and Austria. The newest EU Member States (Slovakia, Lithuania, Latvia, Bulgaria, Hungary and Estonia) are characterized by lower sales and consumption of organic products as well as the smallest organic food markets, with Cyprus being the leader in this group of countries. 


\section{Bibliography}

1. Basha, M.B., Mason, C., Shamsudin, M.F., Hussain, H.I., Salem, M.A. (2015). Consumers Attitude towards Organic Food. Procedia Economics and Finance, Vol. 31, pp. 444-452, https://doi.org/10.1016/S2212-5671(15)01219-8

2. Borawski, P., Beldycka-Borawska, A., Dunn, J.W. (2018). Price Volatility of Polish Agricultural Commodities in the View of the Common Agricultural Policy. Agric. Econ. - Czech, Vol. 64 Issue 5, pp. 216-226. https://doi.org/10.17221/138/2016-AGRICECON

3. Brodziska, K. (2015). Problems of Biodiversity Conservation in Polish Agriculture. Agroecology \& Sustainable Food Systems. Vol. 39, No. 2, pp. 155-169. doi:10.1080/21683565.2014.934941.

4. Council Regulation (EC) No 834/2007 of 28 June 2007 on Organic Production and Labelling of Organic Products and Repealing Regulation (EEC) No 2092/91.

5. GDP and Main Components (output, expenditure and income) [nama_10_gdp] Eurostat. https://ec.europa.eu/eurostat/data/database. Access: 11.12.18.

6. Greenan, K., Humphreys, P., McIvor, R. (1997). The Green Initiative: Improving Quality and Competitiveness. European Business Review, Vol. 97 No. 5, pp. 208-14.

7. $\operatorname{HICP}(2015=100)$ - annual data (average index and rate of change) [prc_hicp_aind]. Eurostat. https://ec.europa.eu/eurostat/data/database. Access: 10.12.18.

8. Krystallis, A., Chryssohoidis, G. (2005). Consumers' Willingness to Pay for Organic Food: Factors That Affect It and Variation Per Organic Product Type. British Food Journal, Vol. 107 Issue: 5, pp. 320-343, https://doi.org/10.1108/00070700510596901

9. Main GDP Aggregates Per Capita [nama_10_pc] Eurostat. https://ec.europa.eu/eurostat/data/database. Access: 07.12 .18 ;

10. Orboi, M. D. (2013). Aspects Regarding the Evolution the Organic Food Market in the World. Research Journal of Agricultural Science, Vol. 45, No. 2, pp. 201-209.

11. Pawlewicz, A. (2014). Importance of Horizontal Integration in Organic Farming. Economic Science for Rural Development: Production and Co-operation in Agriculture. Issue 34, pp. 112-120.

12. Population on 1 January by Age and Sex [demo_pjan] Eurostat. https://ec.europa.eu/eurostat/data/database. Access: 11.12 .18$.

13. Shafie, F. A., Rennie, D. (2012). Consumer Perceptions Towards Organic Food. Procedia-Social and Behavioral Sciences, Vol. 49, pp. 360-367, https://doi.org/10.1016/j.sbspro.2012.07.034

14. The World of Organic Agriculture. Statistics and Emerging Trends 2018. Willer, Helga and Julia Lernoud (Eds.). Research Institute of Organic Agriculture (FiBL), Frick, and IFOAM - Organics International, Bonn, 2018, s. 348

15. Wier, M., Calverley, C. (2002). Market Potential for Organic Foods in Europe. British Food Journal, Vol. 104 Issue: 1 , pp. 45-62, https://doi.org/10.1108/00070700210418749 